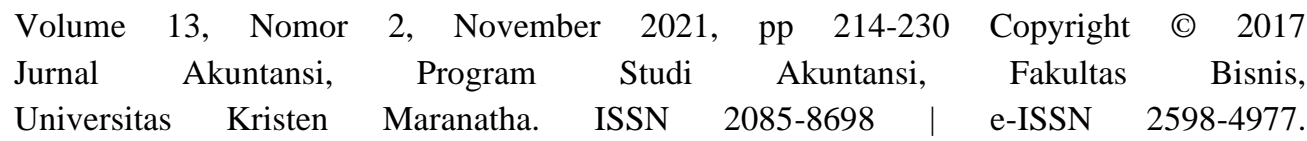

http://journal.maranatha.edu

\title{
Faktor-Faktor yang Mempengaruhi Pertimbangan Tingkat Materialitas Audit (Studi Empiris KAP di Wilayah DKI Jakarta)
}

\author{
Ahmad Rafiq Anshari ${ }^{1}$ \\ Fakultas Ekonomi dan Bisnis, Perbanas Institute Jakarta \\ (Jl. Perbanas, Karet Kuningan, Setiabudi, Jakata Selatan, 12940) \\ rafiqahmad110796@gmail.com \\ Trinandari Prasetyo Nugrahanti ${ }^{2}$ \\ Fakultas Ekonomi dan Bisnis, Perbanas Institute Jakarta \\ (Jl. Perbanas, Karet Kuningan, Setiabudi, Jakata Selatan, 12940) \\ trinandari@perbanas.id
}

\begin{abstract}
This study aims to empirically examine the effect of auditor professionalism, auditor experience and professional ethics on the consideration of the materiality level of financial statement audits. This research method uses a causal descriptive method and the primary data source is obtained by distributing questionnaires to auditors at public accounting firm (KAP) located in DKI Jakarta area using convenience sampling technique. Data analysis was performed using multiple linear regression method and hypothesis testing using SPSS ver.23 program. The results of this study indicate that auditor professionalism, auditor experience and professional ethics have a positive effect on the consideration of the level of audit materiality in financial statements. Auditors in improving a high professionalism attitude must have a lot of audit experience so that it will be appropriate to determine the determination of the materiality level of the financial statements. In carrying out an audit of financial statements, the auditor cannot provide absolute assurance to clients or other users of financial statements that the audited financial statements are free from material misstatement.
\end{abstract}

Keywords :Auditor Professionalism, Auditor Experience, Professional Ethics, and Materiality Levels 


\begin{abstract}
Abstrak
Penelitian ini bertujuan untuk menguji secara empirik pengaruh profesionalisme auditor, pengalaman auditor dan etika profesi terhadap pertimbangan tingkat materialitas audit laporan keuangan.. Metode penelitian ini menggunakan metode deskriptif kausal dan sumber data primer diperoleh dengan cara menyebarkan kuesioner kepada para auditor di Kantor Akuntan Publik berlokasi di wilayah DKI Jakarta dengan menggunakan teknik convenience sampling. Analisis data dilakukan dengan metode regresi linier berganda dan pengujian hipotesis dengan menggunakan program SPSS ver.23. Hasil penelitian ini menunjukkan bahwa profesionalisme auditor, pengalaman auditor dan etika profesi berpengaruh positif terhadap pertimbangan tingkat materialitas audit pada laporan keuangan. Auditor dalam meningkatkan sikap profesionalisme yang tinggi harus memiliki banyaknya pengalaman audit sehingga akan tepat menentukan ketetapan tingkat materialitas atas laporan keuangan. Dalam melaksanakan audit atas laporan keuangan, auditor tidak dapat memberikan jaminan mutlak kepada klien atau pemakai laporan keuangan lainnya bahwa laporan keuangan auditan adalah bebas dari salah saji material.
\end{abstract}

\title{
Kata Kunci : Profesional Audit, Pengalaman Auditor, Etika Profesi, dan Tingkat Materialitas
}

\section{Pendahuluan}

Laporan keuangan harus menyajikan sebuah informasi yang wajar, dapat dipercaya dan tidak menyesatkan bagi penggunanya. Laporan keuangan perlu diaudit oleh profesi akuntan publik sebagai pihak yang kompeten dan independen menurut SA 200 (SPAP, 2013), dengan tujuan untuk memperoleh keyakinan memadai tentang apakah laporan keuangan secara keseluruhan bebas dari salah saji material, baik yang disebabkan oleh kecurangan maupun kesalahan. Oleh karena itu akuntan publik untuk menyatakan suatu opini tentang apakah laporan keuangan disusun oleh manajemen, dalam semua hal yang material, sesuai dengan kriteria yang ditetapkan dan mengkomunikasikannya kepada pengguna.

Menurut SA 321 (SPAP, 2013), materialitas adalah salah satu pertimbangan bagi auditor dalam merumuskan suatu opini. Penentuan materialitas oleh auditor membutuhkan pertimbangan profesional dan pengalaman auditor dalam pengumpulan bahan bukti selama berlangsungnya penugasan audit. Pertimbangan auditor tentang tingkat materialitas merupakan suatu hal yang sangat penting karena seorang auditor tidak dapat memberikan jaminan yang mutlak bagi klien atau pemakai laporan, bahwa laporan keuangan auditan adalah akurat (Arens et al., 2017).

Salah satu fenomena kasus audit yang menarik yaitu, KAP mitra Ernst \& Young's (EY) di Indonesia, yakni KAP Purwantono, Suherman \& Surja sepakat membayar denda senilai US\$ 1 juta (sekitar Rp 13.3 miliar) kepada regulator Amerika Serikat serta memberikan sanksi kepada dua auditor mitra EY yang terlibat dalam audit pada tahun 2011, akibat divonis gagal melakukan audit atas laporan keuangan kliennya.

Kegagalan dalam memperoleh bukti dalam proses pemeriksaan, menentukan tingkat risiko audit, dan ketika auditor menentukan pertimbangan tingkat materialitas. Dalam melaksanakan audit, auditor memutuskan tingkat risiko yang dapat diterima dan merencanakan audit untuk mencapai tingkat risiko audit tersebut. Risiko audit adalah kemungkinan 
auditor memberikan pendapat yang keliru atas laporan keuangan yang mengandung salah saji yang material (Tuanakotta, 2015).

Semua tahapan proses audit sangat tergantung pada sikap profesionalisme auditor dalam mengaudit laporan keuangan kliennya. Profesi akuntan publik memiliki tanggungjawab yang besar dalam menjalankan pekerjaannya dengan kecermatan profesional (due profesional care) guna mengemban kepercayaan yang diberikan kepadanya oleh masyarakat. (Nugrahanti dan Jahja, 2018). Beberapa hasil penelitian dari Khotiyah et al (2016), Sarwini et al (2014), Simanjuntak et al (2017), Halim dan Wulandari (2014), Aryani dan Anggraeni (2018), Nurasik \& Dewi (2018), Rahardjo dan Farouk (2019), yang menunjukkan bahwa profesionalisme auditor berpengaruh terhadap pertimbangan tingkat materialitas. Sementara berbeda dengan hasil penelitian yang dilakukan Sofia dan Damayanti (2017) menunjukan hasil bahwa profesionalisme auditor tidak berpengaruh terhadap pertimbangan tingkat materialitas.

Pengalaman auditor merupakan salah satu elemen penting dalam tugas audit disamping keahlian yang juga harus dimiliki seorang auditor. Kenyataan menunjukkan semakin lama seseorang bekerja maka semakin banyak pengalaman kerja yang dimiliki oleh pekerja tersebut (Nugrahanti, 2012). Menurut hasil beberapa penelitian yang dilakukan Simanjuntak et al (2017), Khotiyah et al (2016), Sarwini et al (2014), Sofia dan Damayanti (2017), Halim dan Wulandari (2014), Sitio (2018) menyatakan bahwa pengalaman auditor berpengaruh terhadap pertimbangan tingkat materialitas. Lain halnya dengan hasil penelitian Lestari dan Utama (2013) yang menunjukkan hasil bahwa pengalaman auditor tidak berpengaruh terhadap pertimbangan tingkat materialitas.

Setiap auditor juga diharapkan memegang teguh etika profesi yang sudah ditetapkan oleh Institut Akuntan Publik
Indonesia. Dengan menjunjung tinggi etika profesi diharapkan tidak terjadi kecurangan dan kelalaian yang dilakukan para auditor, sehingga dapat memberikan pernyataan opini audit yang riil sesuai dengan laporan keuangan yang disusun oleh perusahaan. Beberapa hasil penelitian Rahardjo dan Farouk (2019), Sitio (2018), Sofia dan Damayanti (2017), Aryani dan Anggraeni (2018), Khotiyah et al (2016), Sarwini et al (2014) yang menyatakan bahwa etika profesi berpengaruh terhadap pertimbangan tingkat materialitas. Hal ini bertentangan dengan penelitian yang dilakukan Widarti (2015) yang menunjukan hasil dimana etika profesi tidak berpengaruh terhadap pertimbangan tingkat materialitas.

Manfaat dari penelitian ini bagi auditor yang bekerja Kantor Akuntan Publik, untuk meningkatkan sikap profesionalisme yang tinggi dengan memiliki profesionalisme auditor, pengalaman audit dan menerapkan etika profesi sesuai dengan aturan-aturan yang berlaku, maka auditor akan dapat menentukan ketetapan tingkat materialitas dalam pengauditan laporan keuangan.

\section{Kerangka Teoritis dan Hipotesis}

\section{Teori Perilaku Terencana (Theory of Planned Behavior)}

Teori Perilaku Terencana (Theory of Planned Behavior) merupakan kerangka berpikir konseptual yang bertujuan untuk menjelaskan determinan perilaku tertentu. (Ajzen, 1991). Determinan suatu perilaku merupakan hasil dari penilaian keyakinan keyakinan dari individu, baik sebagai secara positif maupun negatif. Menurut Ajzen (1991), faktor sentral dari perilaku individu adalah bahwa perilaku itu dipengaruhi oleh niat individu (behavior intention) terhadap perilaku tertentu tersebut. Niat untuk berperilaku dipengaruhi oleh tiga komponen yaitu (1) sikap (attitude), (2) norma subjektif (subjective norm) dan (3) persepsi kontrol keperilakuan (perceived behavior control). 
Ketiga hal tersebut yang membentuk intensi dan berpengaruh pula pada perilaku seseorang. Sikap yang mengarah pada perilaku berhubungan dengan locus of control yaitu ketika keberhasilan seseorang ditentukan dari faktor internal atau eksternal . Kaitan dengan norma subjektif adalah ketika auditor berperilaku tidak pofesional dalam menentukan tingkat materialitas maka persepsi tekanan sosial yang akan muncul adalah adanya pelanggaran prinsip serta kode etik akuntan publik yang memang dibuat untuk membatasi sikap dan perilaku auditor dalam pelaksanaan tugasnya agar profesionalitasnya selalu terjaga. Pengendalian perilaku persepsian muncul ketika perilaku seseorang bukan lagi dikendalikan oleh diri sendiri dan juga oleh norma yang berlaku, namun juga oleh faktor lain di luar itu. Penilai kinerja auditor adalah faktor eksternal di luar kendali individu yaitu teman sekerja auditor, baik partner, manajer, supervisor, maupun staf yang dinilai memiliki hubungan dengan penerimaan perilaku profesionalisme auditor dalam menjalankan tugas audit (Nugrahanti dan Nurfaidzah, 2020).

\section{Pertimbangan Tingkat Materialitas}

Materialitas merupakan besarnya informasi akuntansi yang apabila terjadi penghilangan atau salah saji, dilihat dari keadaan yang melingkupinya, mungkin dapat mengubah atau mempengaruhi pertimbangan orang yang meletakkan kepercayaan atas informasi tersebut (Messier et al., 2014). Dalam SPAP SA 320 (2013) konsep materialitas diterapkan oleh auditor pada tahap perencanaan dan pelaksanaan audit, serta pada saat mengevaluasi dampak kesalahan penyajian teridentifikasi dalam audit dan kesalahan penyajian yang tidak dikoreksi, jika ada, terhadap laporan keuangan dan pada saat merumuskan opini dalam laporan auditor (SPA 320, Paragraf 5).
Berdasarkan KEP-347/BL/2012 tentang Penyajian Dan Pengungkapan Laporan Keuangan Emiten Atau Perusahaan Publik telah ditetapkan tingkat materialitas, yaitu: 1) $5 \%$ (lima perseratus) dari jumlah seluruh Aset untuk pos-pos Aset; 2) 5\% (lima perseratus) dari jumlah seluruh Liabilitas untuk pos-pos Liabilitas; 3) 5\% (lima perseratus) dari jumlah seluruh ekuitas untuk pos-pos ekuitas; 4) 10\% (sepuluh perseratus) dari pendapatan untuk pospos laba rugi komprehensif; 5) $10 \%$ (sepuluh perseratus) dari laba dari operasi yang dilanjutkan sebelum pajak untuk pengaruh suatu peristiwa atau transaksi (Peraturan Nomor VIII.G.7).

Haryono (2001:212-215) menerangkan ada empat indikator dalam menentukan tingkat materialitas, yaitu: (1) Pertimbangan awal materialitas, (2) Materialitas pada tingkat laporan keuangan, (3) Materialitas pada tingkat akun, (4) Alokasi materialitas pada tingkat laporan keuangan. Keempat hal diatas menjadi indikator dari variabel pertimbangan tingkat materialitas dalam penelitian ini.

\section{Profesionalisme Auditor}

Dalam ISA 200 dalam SPAP (2013), profesional audit dipengaruhi oleh pengetahuan dan pengalaman yang relevan, dalam konteks auditing, akuntansi dan standar etika, untuk mencapai keputusan yang tepat dalam situasi atau keadaan selama penugasan audit dan auditor (Tuanakotta, 2015). Sikap profesionalisme auditor adalah sikap tanggung jawab untuk bertindak lebih dari sekedar memenuhi tanggung jawab kepada diri sendiri maupun ketentuan hukum yang berlaku dan peraturan masyarakat. (Arens et al., 2017). Menurut Hall (1968) terdapat lima dimensi profesionalisme eksternal auditor, yaitu: a) Pengabdian pada profesi. b) Kewajiban sosial. c) Kemandirian. d) Keyakinan terhadap profesi. e) Hubungan dengan sesama rekan profesi. 
Beberapa penelitian yang dilakukan Khotiyah et al (2016), Sarwini et al (2014), Simanjuntak et al (2017), Halim dan Wulandari (2014), Aryani dan Anggraeni (2018), Nurasik \& Dewi (2018), Rahardjo dan Farouk (2019) yang menyatakan bahwa pertimbangan profesional auditor berpengaruh terhadap pertimbangan tingkat materialitas. Berdasarkan uraian diatas, maka hipotesis yang dapat diambil dalam penelitian ini adalah:

$\mathbf{H}_{1}$ : Profesionalisme Auditor Berpengaruh Positif Terhadap Pertimbangan Tingkat Materialitas

\section{Pengalaman Auditor}

Pengalaman audit dapat diartikan sebagai pengalaman auditor dalam melakukan audit laporan keuangan baik dari segi lamanya waktu maupun banyaknya penugasan yang pernah dilakukannya. Pertimbangan profesional dari auditor berpengalaman akan lebih intuitif dibanding dengan auditor yang kurang berpengalaman. (Agoes, 2016).

Pengalaman kerja merupakan suatu proses pembelajaran dan penambahan perkembangan potensi bertingkah laku baik dari pendidikan formal maupun non formal atau bisa juga diartikan sebagai suatu proses yang membawa seseorang kepada suatu pola tingkah laku yang lebih tinggi. Menurut Tubbs (1992) pengalaman auditor dapat diukur berdasarkan tiga aspek yaitu: a) Lamanya auditor bekerja, b) Banyaknya penugasan yang ditangani, c) Banyaknya jenis perusahaan yang pernah diaudit.

Beberapa hasil penelitian Simanjuntak et al (2017), Khotiyah et al (2016), Sarwini et al (2014), Sofia dan Damayanti (2017), Halim dan Wulandari (2014), Sitio (2018) yang menyatakan bahwa pengalaman auditor berpengaruh terhadap pertimbangan tingkat materialitas. Berdasarkan uraian diatas, maka hipotesis yang dapat diambil dalam penelitian ini adalah:
$\mathbf{H}_{2}$ : Pengalaman Auditor Berpengaruh Positif Terhadap Pertimbangan Tingkat Materialitas.

\section{Etika Profesi}

Kode Etik Profesi Akuntan Publik yang baru saja diterbitkan oleh IAPI (2018) menyebutkan ada 5 prinsip-prinsip dasar etika profesi, yaitu: 1) Prinsip Integritas, 2) Prinsip Objektivitas, 3) Prinsip Kompetensi Profesional dan Sikap Cermat Kehatihatian, 4) Prinsip Kerahasiaan, 5) Prinsip Perilaku Profesional.

Beberapa hasil penelitian Rahardjo dan Farouk (2019), Sitio (2018), Sofia dan Damayanti (2017), Aryani dan Anggraeni (2018), Khotiyah et al (2016), Sarwini et al (2014) yang menyatakan bahwa etika profesi berpengaruh terhadap pertimbangan tingkat materialitas. Kenyataan menunjukkan semakin lama seseorang bekerja maka semakin banyak pengalaman kerja yang dimiliki oleh pekerja tersebut. Sebaliknya, semakin singkat masa kerja seseorang biasanya semakin sedikit pula pengalaman yang diperolehnya. Pengalaman bekerja memberikan keahlian dan keterampilan dalam kerja, sedangkan keterbatasan pengalaman kerja mengakibatkan tingkat keterampilan dan keahlian yang dimiliki semakin rendah. Ini biasanya terbukti dari kesalahan yang dilakukan dalam bekerja dan hasil kerja yang belum maksimal. Berdasarkan uraian diatas, maka hipotesis yang dapat diambil dalam penelitian ini adalah:

$\mathbf{H}_{3}$ : Etika Profesi Berpengaruh Positif Terhadap Pertimbangan Tingkat Materialitas

\section{Metode Penelitian}

\section{Jenis Penelitian}

Pendekatan kuantitatif digunakan pada studi ini. Metode penelitian ini menggunakan pendekatan kausalitas, yaitu penelitian yang bertujuan untuk menganalisis hubungan antara satu variabel dengan variabel lainnya atau bagaimana 
suatu variabel mempengaruhi suatu variabel lain (Sugiyono (2017). Penelitian ini bertujuan untuk mengkaji hubungan sebab dan akibat (causal) karena menelusuri pengaruh profesionalisme auditor, pengalaman auditor dan etika profesi terhadap pertimbangan tingkat materialitas.

\section{Populasi dan Sampel}

Populasi adalah wilayah generalisasi yang terdiri atas: objek atau subjek yang mempunyai kualitas dan karakteristik tertentu yang ditetapkan oleh peneliti untuk dipelajari dan kemudian ditarik kesimpulannya. Populasi mengacu pada keseluruhan kelompok orang, kejadian, atau hal minat yang ingin diteliti oleh peneliti (Sugiyono, 2017). Populasi dalam penelitian ini adalah para auditor pada Kantor Akuntan Publik (KAP) yang berada di Jakarta Selatan dan Jakarta Pusat yang terdaftar pada OJK sebanyak 43 Kantor Akuntan Publik. Sampel dalam penelitian ini menggunakan teknik convenience sampling yaitu pengambilan sampel didasarkan pada ketersediaan elemen dan kemudahan untuk mendapatkannya (Sugiyono, 2017). Sampel diambil atau terpilih karena sampel tersebut ada pada tempat dan waktu yang tepat. Dalam penelitian ini ditentukan kriterianya adalah beberapa KAP dengan kemudahan dan ketersediaannya yang terdapat di daerah Jakarta Selatan dan Jakarta Pusat yang terdaftar pada OJK. Kriteria responden dalam penelitian ini adalah seluruh auditor yang berhubungan langsung dengan perencanaan, proses dan pelaksanaan kegiatan audit yang terdiri dari: auditor senior, auditor manajer, auditor supervisor dan partner.

\section{Variabel Penelitian}

Variabel terikat yaitu variabel yang dipengaruhi atau yang menjadi akibat karena adanya variabel bebas (Sugiyono, 2017:16). Pada penelitian ini variabel terikat adalah tingkat pertimbangan materialitas sebagai variabel yang dipengaruhi. Sedangkan variabel bebas merupakan variabel yang mempengaruhi atau menjadi sebab perubahannya atau timbulnya perubahan dependen (terikat). Variabel bebas dalam penelitian ini adalah profesionalisme auditor, etika profesi, dan pengalaman auditor.

Indikator variabel pertimbangan tingkat materialitas dalam penelitian ini ada 4 (empat), yaitu: (1) Pertimbangan awal materialitas, (2) Materialitas pada tingkat laporan keuangan, (3) Materialitas pada tingkat akun, (4) Alokasi materialitas pada tingkat laporan keuangan (Haryono, 2001:212-215). Sedangkan dimensi variabel profesionalisme auditor dalam penelitian ini ada 5 (lima), yaitu: a) Pengabdian pada profesi. b) Kewajiban sosial. c) Kemandirian. d) Keyakinan terhadap profesi. e) Hubungan dengan sesama rekan profesi (Hall, 1968). Selanjutnya dimensi variabel pengalaman auditor dapat diukur berdasarkan tiga aspek yaitu: a) Lamanya auditor bekerja, b) Banyaknya penugasan yang ditangani, c) Banyaknya jenis perusahaan yang pernah diaudit (Tubbs, 1992). Kemudian dimensi variabel etika profesi terdapat 5 prinsipprinsip dasar etika profesi, menurut Kode Etik Profesi Akuntan Publik yang baru saja diterbitkan oleh IAPI (2018), yaitu: 1) Prinsip Integritas, 2) Prinsip Objektivitas, 3) Prinsip Kompetensi Profesional dan Sikap Cermat Kehati-hatian, 4) Prinsip Kerahasiaan, 5) Prinsip Perilaku Profesional.

\section{Teknik Pengumpulan Data}

Metode pengumpulan data yang digunakan dalam penelitian ini adalah metode kuesioner, dengan cara menyebarkan kuesioner kepada para auditor yang bekerja di Kantor Akuntan Publik Jakarta Selatan dan Jakarta Pusat. Kuesioner merupakan teknik pengumpulan data yang dilakukan dengan cara memberi seperangkat pertanyaan atau pernyataan tertulis kepada para responden untuk dijawabnya 
(Sugiyono, 2017). Jenis data yang digunakan dalam penelitian ini antara lain data primer dan sekunder.

\section{Uji Kualitas Data}

Uji kualitas data dilakukan dengan uji validitas dan uji reliabilitas dengan menggunakan program SPSS versi 23. Pengujian validitas dilakukan dengan teknik korelasi bivariate (person correlation). Untuk uji reliabilitas, suatu variabel dikatakan reliabel jika memberikan nilai Crobanch Alpha > 0,70 (Ghozali, 2018:48). Uji asumsi klasik dalam penelitian ini meliputi uji normalitas, uji multikolinearitas, dan uji heteroskedastisitas. Uji normalitas dilakukan dengan menggunakan uji Kolmogorov-Smirnov, grafik histogram, dan kurva penyebaran P-Plot (Ghozali, 2012:160). Uji multikolinearitas dilakukan dengan melihat nilai tolerance dan Variance Inflation Factor (VIF). Adanya gejala multikolinearitas, menurut Ghozali (2012:106) adalah mempunyai VIF $\geq 10$ dan mempunyai angka tolerance $\leq 0,10$. Uji heteroskedastisitas dilakukan dengan menggunakan metode scatter plot, dengan melihat ada tidaknya pola tertentu pada grafik scatter plot.

\section{Teknik Analisis Data}

Data dalam penelitian ini dianalisis lebih lanjut menggunakan analisis koefisien determinasi dan analisis regresi linier berganda. Kriteria apabila hipotesis diterima adalah jika $\mathrm{P}$ value (sig) $<\alpha$ sebesar 0,05 dan jika koefisien regresi searah dengan hipotesis. Secara umum formulasi dari regresi linier berganda dapat dirumuskan sebagai berikut:

$$
\mathbf{Y}=\mathbf{a}+\mathbf{b}_{1} \mathbf{X}_{1}+\mathbf{b}_{2} \mathbf{X}_{2}+\mathbf{b}_{3} \mathbf{X}_{3}+\mathbf{e}
$$

Dimana :

$\mathrm{Y}=$ pertimbangan tingkat materialitas

$\mathrm{a}=$ konstanta

$\mathrm{b}=$ koefisien regresi

$\mathrm{X}_{1}=$ variabel profesionalisme auditor
$\mathrm{X}_{2}=$ variabel pengalaman auditor

$\mathrm{X}_{3}=$ variabel etika profesi

$\mathrm{e}=$ error

Pengujian hipotesis dapat dilakukan dengan uji parsial (uji t) maupun uji simultan (uji F). Uji Parsial (t-test) menguji pengaruh antara variabel independen (X) yaitu profesionalisme auditor, pengalaman auditor dan etika profesi terhadap variabel dependen (Y) yaitu pertimbangan tingkat materialitas, dengan asumsi bahwa variabel lain dianggap konstan

\section{Analisis Hasil Penelitian Dan Pembahasan}

\section{Deskripsi Objek Penelitian}

Objek yang digunakan dalam penelitian ini adalah Kantor Akuntan Publik (KAP). Sebelum melakukan penyebaran kuesioner secara luas, peneliti terlebih dahulu mencoba melakukan survei atas kuesioner kepada 5 auditor untuk mengetahui apakan kuesioner yang diberikan dapat dipahami. Selanjutnya, peneliti melakukan penelitian pada 43 KAP di wilayah DKI Jakarta dan mendapatkan responden sebanyak 88 dengan kriteria auditor senior, auditor manajer, auditor supervisor, dan partner. Adapun proses penyebaran dan pengembalian kuesioner untuk seleksi sampel sebagai berikut :

\section{Tabel 1}

Penyebaran dan Pengembalian

Kuesioner

\begin{tabular}{|l|c|c|}
\hline \multicolumn{1}{|c|}{ Kuesioner } & Jumlah & $\mathbf{( \% )}$ \\
\hline Kuesioner yang disebar & 110 & 100 \\
\hline $\begin{array}{l}\text { Kuesioner yang tidak } \\
\text { kembali }\end{array}$ & $(17)$ & 15 \\
\hline $\begin{array}{l}\text { Kuesioner kembali dan } \\
\text { tidak dapat diolah }\end{array}$ & $(5)$ & 5 \\
\hline $\begin{array}{l}\text { Kuesioner yang kembali } \\
\text { dan dapat diolah }\end{array}$ & 88 & 80 \\
\hline
\end{tabular}

Sumber Data: diolah oleh peneliti 
Berdasarkan keterangan tabel 1. memperlihatkan bahwa jumlah kuesioner yang disebarkan ke 43 KAP sebanyak 110 buah. Sedangkan kuesioner yang tidak kembali sebanyak 17 disebabkan responden telah resign dari KAP dan kuesioner kembali tapi tidak dapat diolah sebanyak 5 disebabkan kuesioner tidak lengkap diisi responden, sehingga kuesioner yang dapat diolah dan digunakan dalam penelitian ini sebanyak 88 kuesioner atau $80 \%$ dari total kuesioner yang disebarkan.

\section{Deskripsi Responden}

Pada tabel 2 dibawah ini memperlihatkan deskripsi responden berdasarkan jenis kelamin dapat diketahui bahwa, dari total 88 orang responden terdapat 55 orang atau $62.5 \%$ responden dengan jenis kelamin Pria dan 33 orang atau $37.5 \%$ responden dengan jenis kelamin Wanita. Dengan demikian, respoden dalam penelitian ini didominasi oleh responden dengan jenis kelamin lakilaki. Sedangkan berdasarkan umur responden, diketahui bahwa jumlah responden dengan usia dibawah 25 tahun sebanyak 12 orang atau $13.6 \%$, usia 26-35 tahun sebanyak 34 orang atau $38.6 \%$, dan usia 36-50 tahun sebanyak 42 orang atau $47.8 \%$ dari total responden. Dapat disimpulkan bahwa, responden dalam penelitian ini didominasi oleh responden usia 36-50 tahun. Sementara berdasarkan pendidikan terakhir yang ditempuh oleh responden yaitu, jenjang pendidikan S3 sebanyak 5 orang atau $5.7 \%$, S2 sebanyak 14 orang atau $15.9 \%$, dan S1 sebanyak 69 orang atau $78.4 \%$ dari total responden. Dapat disimpulkan, responden dalam penelitian ini didominasi dengan jenjang pendidikan terakhir S1. Sedangkan berdasarkan jabatan responden, maka dapat dijelaskan bahwa jabatan auditor di KAP yaitu, auditor senior sebanyak 31 orang atau $35.2 \%$, auditor supervisor sebanyak 15 orang atau $17 \%$, auditor manajer sebanyak 23 orang atau $26,2 \%$ dan partner sebanyak 19 orang atau $21,6 \%$ dari total responden.
Dapat disimpulkan, responden dalam penelitian didominasi dengan jabatan auditor senior. Selanjutnya lama bekerja sebagai auditor yaitu antara 1-5 tahun sebanyak 63 orang atau $71.6 \%$, antara 6-10 tahun sebanyak 17 orang atau $19.4 \%$ dari total responden, dan 8 orang telah bekerja lebih dari 10 tahun atau 9\% dari total responden. Dapat disimpulkan bahwa responden dalam penelitian didominasi oleh responden yang sudah bekerja antara 1-5 tahun sebagai auditor sebanyak 63 orang atau $71.6 \%$ dari total responden.

Tabel 2

Deskripsi Responden

\begin{tabular}{|c|c|c|c|c|}
\hline \multicolumn{5}{|c|}{ Jenis Kelamin Responden } \\
\hline & $\begin{array}{l}\text { Fre } \\
\text { que } \\
\text { ncy }\end{array}$ & Percent & $\begin{array}{c}\text { Valid } \\
\text { Percent }\end{array}$ & $\begin{array}{c}\text { Cumu } \\
\text { lative } \\
\text { Perce } \\
\text { nt }\end{array}$ \\
\hline Valid Pria & 55 & 62.5 & 62.5 & 62.5 \\
\hline Wanita & 33 & 37.5 & 37.5 & 100.0 \\
\hline Total & 88 & 100.0 & 100.0 & \\
\hline \multicolumn{5}{|c|}{ Umur Responden } \\
\hline & $\begin{array}{l}\text { Fre } \\
\text { que } \\
\text { ncy }\end{array}$ & Percent & $\begin{array}{c}\text { Valid } \\
\text { Percent }\end{array}$ & $\begin{array}{c}\text { Cumu } \\
\text { lative } \\
\text { Perce } \\
\text { nt }\end{array}$ \\
\hline Valid $<25$ & 12 & 13.6 & 13,6 & 13,6 \\
\hline $26-35$ & 34 & 38.6 & 38.6 & 52,2 \\
\hline $36-50$ & 42 & 47,8 & 47,8 & 100.0 \\
\hline Total & 88 & 100.0 & 100.0 & \\
\hline \multicolumn{5}{|c|}{ Pendidikan Terakhir Responden } \\
\hline & $\begin{array}{l}\text { Fre } \\
\text { que } \\
\text { ncy }\end{array}$ & Percent & $\begin{array}{c}\text { Valid } \\
\text { Percent }\end{array}$ & $\begin{array}{c}\text { Cumu } \\
\text { lative } \\
\text { Perce } \\
\text { nt }\end{array}$ \\
\hline
\end{tabular}




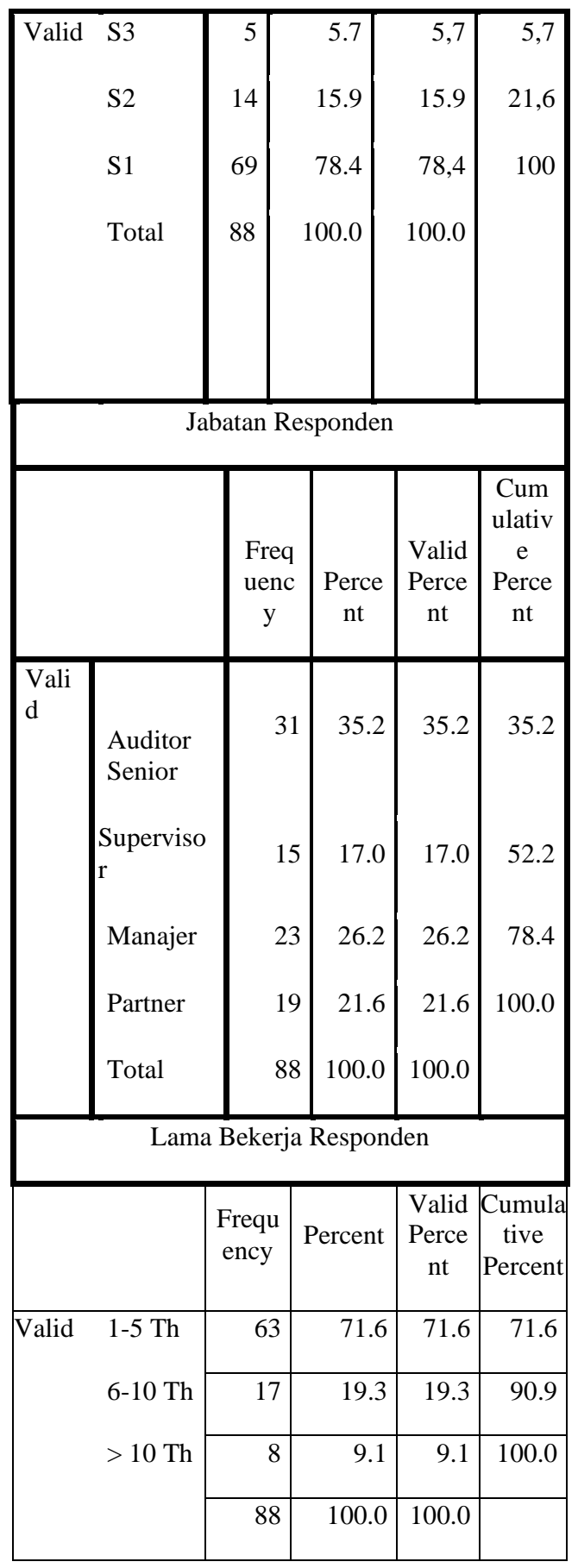

Hasil data statistik deskriptif pada tabel 3 dibawah ini menunjukkan bahwa profesionalisme auditor memiliki nilai ratarata (mean) sebesar 43.0909 dan standar errornya adalah 0.35874 , dengan nilai standar deviasi sebesar 3.36526. Pengalaman auditor memiliki nilai rata-rata sebesar 28.6591 dan standar errornya adalah 0.28590, dengan nilai standar deviasi sebesar 2.68194. Etika profesi memiliki nilai rata-rata sebesar 52.1818 dan standar errornya adalah 0.43114 , dengan nilai standar deviasi sebesar 4.04442. Dan pertimbangan tingkat materialitas memikili nilai rata-rata sebesar 53.7841 dan standar errornya adalah 0.43443 , dengan nilai standar deviasi sebesar 4.07529.

Tabel 3

Tabel Statistik Deskriptif Descriptive Statistics

\begin{tabular}{|c|c|c|c|c|c|}
\hline & $\mathrm{N}$ & Min. & Max. & Mean & $\begin{array}{l}\text { Std. } \\
\text { Dev. }\end{array}$ \\
\hline & $\begin{array}{l}\text { Stat } \\
\text { istic }\end{array}$ & $\begin{array}{c}\text { Statist } \\
\text { ic }\end{array}$ & $\begin{array}{c}\text { Statist } \\
\text { ic }\end{array}$ & $\begin{array}{c}\text { Statist } \\
\text { ic }\end{array}$ & $\begin{array}{c}\text { Statist } \\
\text { ic }\end{array}$ \\
\hline $\begin{array}{l}\text { Profesionali } \\
\text { sme Auditor } \\
\text { _(X1) }\end{array}$ & 88 & 35.00 & 50.00 & 43.091 & 3.3653 \\
\hline $\begin{array}{l}\text { Pengalaman } \\
\text { Auditor_(X } \\
2)\end{array}$ & 88 & 22.00 & 35.00 & 28.659 & 2.6819 \\
\hline $\begin{array}{l}\text { Etika } \\
\text { Profesi_- } \\
\text { (X3) }\end{array}$ & 88 & 39.00 & 60.00 & 52.182 & 4.0444 \\
\hline $\begin{array}{l}\text { Pertimbanga } \\
\mathrm{n} \text { Tingkat } \\
\text { Materialitas } \\
\text { (Y) }\end{array}$ & 88 & 43.00 & 65.00 & 53.784 & 4.0753 \\
\hline $\begin{array}{l}\text { Valid N } \\
\text { (listwise) }\end{array}$ & 88 & & & & \\
\hline
\end{tabular}

Sumber: Data diolah dengan menggunakan aplikasi SPSS ver. 23

Sumber : Data diolah dengan menggunakan aplikasi IBM SPSS 23 


\section{Analisis Hasil Penelitian}

Ketepatan pengujian hipotesis sangat tergantung pada kualitas data yang dipakai dalam pengujian tersebut. Data penelitian tidak akan berguna bilamana instrumen yang digunakan untuk mengumpulkan data tidak memiliki validitas dan reliabilitas yang memenuhi persyaratan minimal. Hasil uji validitas menunjukkan bahwa semua butir pertanyaan pada kuesioner untuk variabel profesionalisme auditor, Pengalaman Auditor, Etika Profesi dan Pertimbangan Tingkat Materialitas adalah valid, karena $r$ hitung $>r$ tabel. Selanjutnya hasil uji reliabilitas untuk variabel profesionalisme auditor mempunyai nilai alpha cronbach sebesar 0.742 , variabel pengalaman auditor mempunyai nilai alpha cronbach sebesar 0.723, variabel etika profesi mempunyai nilai alpha cronbach sebesar 0.814, dan variabel pertimbangan tingkat materialitas mempunyai nilai alpha cronbach sebesar 0.809. Jadi dapat disimpulkan bahwa semua variabel dalam penelitian ini adalah reliabel karena setiap variabel memiliki nilai alpha cronbach $>0.70$. Uji asumsi klasik dalam penelitian ini meliputi uji normalitas, uji multikolinearitas, dan uji heteroskedastisitas. Hasil pengujian normalitas sudah menunjukkan data terdistribusi secara normal, yang dilakukan melalui metode grafik. Pada grafik gambar 1 tersebut dapat dilihat bahwa titik-titik dari gambar Normal P-P Plot di atas relatif mendekati garis lurus. Oleh karena itu dapat disimpulkan bahwa (data) residual terdistribusi normal.

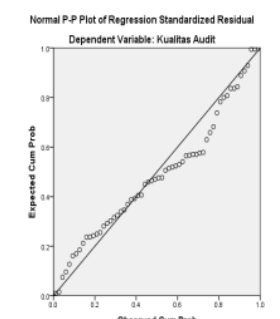

Gambar 1.

Hasil Uji Normalitas
Sumber: Data diolah dengan menggunakan aplikasi SPSS ver. 23

Dan hasil uji multikolinearitas pada dilihat pada tabel 4 yang telah dilakukan dapat diketahui bahwa nilai VIF untuk variabel profesionalisme auditor (X1) sebesar 1.670, Pengalaman Auditor (X2) sebesar 1.621 dan Etika Profesi (X3) sebesar 1.268, sehingga nilai VIF setiap variabel $\leq 10$. Sedangkan nilai tolerance untuk variabel profesionalisme auditor (X1) sebesar 0.599, Pengalaman Auditor (X2) sebesar 0.617 dan Etika Profesi (X3) sebesar 0.789, sehingga nilai tolerance $\geq 0,1$. Karena setiap variabel bebas dalam penelitian ini nilai VIF $\leq 10$ dan nilai tolerance $\geq 0,1$, maka dapat disimpulkan bahwa tidak terjadi multikolinearitas pada ketiga variabel bebas tersebut.

Tabel 4

Hasil Uji Multikolinearitas

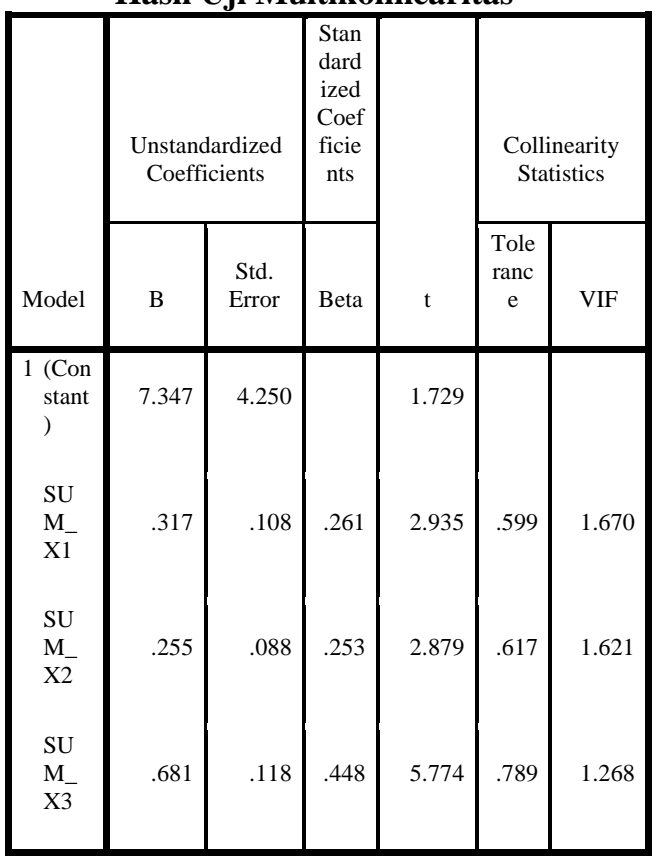

Sumber : Data diolah dengan menggunakan aplikasi IBM SPSS 23

Kemudian pengujian heteroskedastisitas dilakukan dengan membuat scatter plot (alur sebaran) antara residual dan nilai 
prediksi dari variabel terikat yang telah distandarisasi. Dalam scatter plot (alur sebaran) terlihat bahwa sebaran titik tidak membentuk suatu pola/alur tertentu, titiktitik tersebar diatas maupun dibawah angka 0 pada sumbu $\mathrm{Y}$, dan tidak menumpuk disuatu tempat. Sehingga dapat disimpulkan tidak terjadi heteroskedastisitas atau dengan kata lain terjadi homoskedastisitas. Asumsi klasik tentang heteroskedastisitas dalam model ini terpenuhi, yaitu terbebas dari heteroskedastisitas. Selanjutnya hasil uji multikolinearitas dapat dilihat dalam gambar 2. dibawah ini.

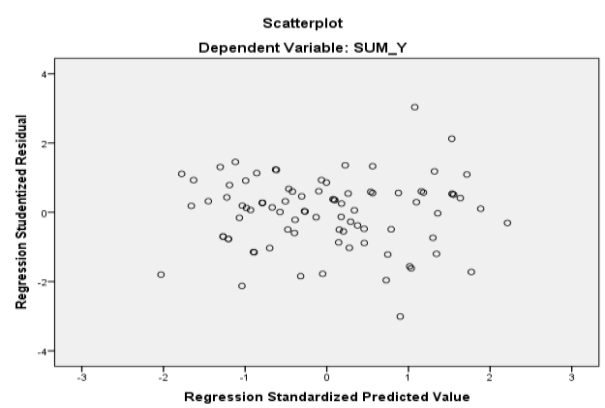

Gambar 2

Hasil Uji Heteroskedastisitas

Sumber : Data diolah dengan menggunakan aplikasi IBM SPSS 23

Selanjutnya data dalam penelitian ini dianalisis dengan menggunakan analisis koefisien determinasi dan analisis regresi linier berganda. Hasil uji koefisien determinasi bertujuan untuk mengukur seberapa jauh kemampuan model dapat menjelaskan variasi variabel dependen. adapun hasil Uji Koefisien Determinasi (R2) terlihat pada table 5. sebagai berikut:
Tabel 5

Hail U.ji koefisien Determinasi

\begin{tabular}{|l|r|r|r|r|}
\hline $\begin{array}{l}\text { Mode } \\
1\end{array}$ & $\mathrm{R}$ & $\begin{array}{c}\mathrm{R} \\
\text { Square }\end{array}$ & $\begin{array}{c}\text { Adjusted } \\
\text { R Square }\end{array}$ & $\begin{array}{c}\text { Std. Error } \\
\text { of the } \\
\text { Estimate }\end{array}$ \\
\hline 1 & $.775^{\mathrm{a}}$ & .601 & .587 & 2.61986 \\
\hline
\end{tabular}

a. Predictors: (Constant), profesionalisme auditor _X1, Pengalaman_X2, Etika Profesi_X3

b. Dependent Variable: Pertimbangan Tingkat Materialitas_Y

Sumber : Data diolah dengan menggunakan aplikasi IBM SPSS 23

Berdasarkan tabel, nilai determinasi yang sudah disesuaikan (Adjusted R Square) adalah 0,587 . Hal ini berarti $58,7 \%$ variasi dari pertimbangan tingkat materialitas dapat dijelaskan oleh variasi variabel independen yakni profesionalisme auditor, pengalaman auditor dan etika profesi yang terdapat dalam penelitian ini. Sedangkan sisanya sebesar $41,3 \%$ dipengaruhi oleh variabel lain yang tidak ada dalam penelitian ini. Selanjutnya dilakukan uji regresi berganda dan uji hipotesis. dilakukan uji regresi berganda dan uji hipotesis. Uji analisis regresi linier berganda terlihat pada tabel 6digunakan untuk mengetahui pengaruh antara variabel independen terhadap variabel dependen. 


\section{Tabel 6}

\section{Hasil Uji Regresi Linier Berganda dan} Hasil Analisis Uji t

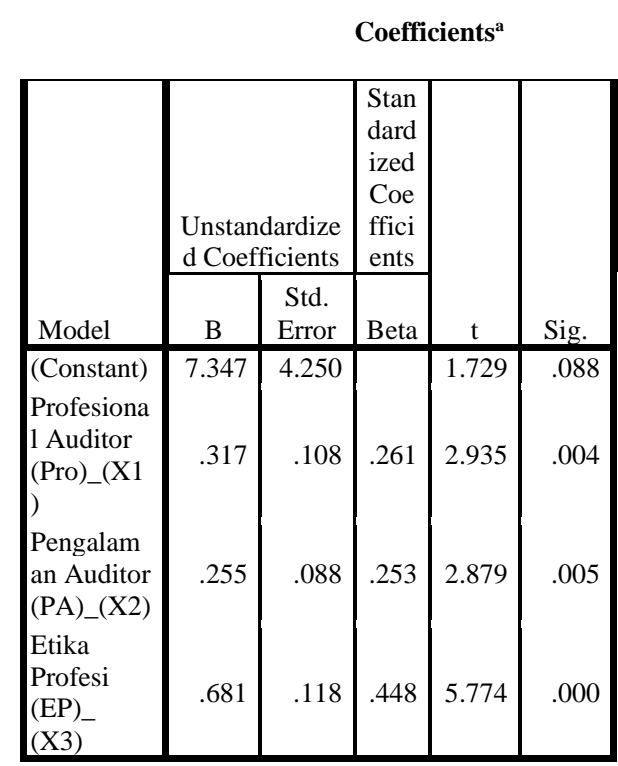

a. Dependent Variable: Pertimbangan Tingkat Materialitas_(Y)

Sumber : Data diolah dengan menggunakan aplikasi IBM SPSS 23

Model persamaan regresi linier berganda untuk penelitian ini sebagai berikut :

$$
\begin{aligned}
\mathrm{Y}= & \alpha+\beta 1 \mathrm{X} 1+\beta 2 \mathrm{X} 2+\beta 3 \mathrm{X} 3+\mathrm{e} \\
\mathrm{Y}= & 7.347+0.317 \mathrm{AJ}+0.255 \mathrm{PA}+ \\
& 0.681 \mathrm{EP}+\mathrm{e}
\end{aligned}
$$

Tabel 7

\section{Hasil Uji F}

ANOVA $^{\mathrm{a}}$

\begin{tabular}{|l|r|r|r|r|r|}
\hline Model & $\begin{array}{c}\text { Sum of } \\
\text { Squares }\end{array}$ & $\begin{array}{c}\text { D } \\
\text { f }\end{array}$ & $\begin{array}{c}\text { Mean } \\
\text { Square }\end{array}$ & F & Sig. \\
\hline 1Regressi & 868.352 & 3 & 289.451 & 42.172 & $\begin{array}{r}.000 \\
\text { b }\end{array}$ \\
Residual & 576.546 & 84 & 6.864 & & \\
Total & 1444.898 & 87 & & & \\
\hline
\end{tabular}

a. Dependent Variable: Pertimbangan Tingkat

Materialitas_(Y)

b. Predictors: (Constant), profesionalisme auditor_X1, Pengalaman_X2, Etika Profesi_X3

Sumber : Data diolah dengan menggunakan aplikasi IBM SPSS 23

Pada tabel 7 hasil uji ANOVA (Analysis of Variance) atau uji F, diperoleh nilai Fhitung sebesar 42.172 dengan nilai probabilitas $(\mathrm{sig})=0.000$. Nilai $\mathrm{F}$ hitung (42.172) > F tabel (2.71), dan nilai sig. lebih kecil dari nilai probabilitas 0.05 atau nilai $0.000<0.05$, maka dapat disimpulkan secara bersama-sama (simultan) profesionalisme auditor, pengalaman auditor, dan etika profesi berpengaruh signifikan terhadap pertimbangan tingkat materialitas. Semakin tinggi profesionalisme auditor atau tingkat pertimbangan profesionalisme akuntan publik, pengalaman yang dimilikinya dan ketaatannya akan kode etik, maka semakin baik pula pertimbangan tingkat materialitasnya. Artinya, dengan sikap adanya pertimbangan profesionalisme auditor yang tinggi akan mempengaruhi penetapan tingkat materialitas. Semakin banyak pengalaman yang didapat oleh auditor, akan semakin bertambah pula pengetahuan, keahlian serta untuk menemukan kesalahan dan kekeliruan terutama dalam menentukan ketepatan penetapan tingkat materialitas. Disamping itu dalam memegang teguh etika profesi dari suatu keputusan yang dihasilkan oleh 
seorang auditor dalam mempertimbangkan tingkat materialitas akan lebih independen dan objektif.

\section{Pembahasan Hasil Penelitian}

\section{Pengaruh Profesionalisme Auditor Terhadap Pertimbangan Tingkat Materialitas}

Hasil uji hipotesis pertama (H1) diterima, yaitu profesionalisme auditor berpengaruh positif terhadap pertimbangan tingkat materialitas pada auditor yang bekerja di KAP wilayah DKI Jakarta. Pada tabel 6 coefficients dapat diketahui bahwa nilai sig untuk uji $\mathrm{t}$ sebesar $0.004<0.05$, nilai $\mathrm{t}$ hitung $2.935>1.987$ nilai t tabel. Nilai sig. dibawah 0.05 artinya bahwa variabel profesionalisme auditor memiliki pengaruh yang signifikan terhadap pertimbangan tingkat materialitas. Dilihat dari nilai $\mathrm{t}$ hitung yang lebih besar dari nilai t tabel juga mengindikasikan bahwa variabel profesionalisme auditor berpengaruh terhadap pertimbangan tingkat materialitas. Selanjutnya nilai Beta yaitu untuk melihat arah pengaruh dari variabel independen terhadap variabel dependennya. Pada nilai Beta di tabel 4 bisa dilihat bahwa hasilnya positif, maka pengaruhnya positif. Sehingga dapat disimpulkan H1 diterima, yaitu variabel profesionalisme auditor (X1) berpengaruh signifikan positif terhadap pertimbangan tingkat materialitas $(\mathrm{Y})$.

Profesionalisme auditor sangat dibutuhkan dalam menentukan ketetapan penetapan tingkat materialitas sehingga dengan sikap profesionalisme yang tinggi maka auditor akan menjalankan pekerjaan sesuai dengan aturan-aturan yang berlaku dan cenderung menyelesaikan tahapantahapan proses audit secara lengkap. Seorang auditor yang memiliki pertimbangan audit profesional akan lebih tepat dalam mengaudit laporan keuangan sesuai dengan keadaan yang sebenarnya. Semakin tinggi tingkat profesionalisme akuntan publik, maka semakin baik pula pertimbangan tingkat materialitasnya.
Sebagian besar auditor setuju atas pentingnya profesionalisme auditor yang harus dimiliki auditor dalam melakukan tugas audit, dengan memperhatikan (1) pengetahuan, kompetensi, pengalaman dan pengabdiannya pada profesi meskipun imbalan ekstrinsiknya kurang, (2) memiliki kewajiban sosial dengan memberikan manfaat jasa audit untuk klien dan menjaga kepercayaan masyarakat atas hasil audit sesuai dengan fakta yang ada, (3) kemandirian auditor harus mampu membuat keputusan sendiri tanpa ada tekanan dari pihak lain, (4) keyakinan yang tinggi pada profesi melalui ikatan profesi akuntan publik sehingga dapat membangun kesadaran profesional, dan (5) hubungan sesama rekan profesi melalui penilaian profesional sesama rekan profesi, bukan orang luar yang tidak mempunyai kompetensi dalam bidang ilmu dan pekerjaan audit. Semakin tinggi tingkat profesionalisme akuntan publik maka semakin tinggi juga dalam menilai dan menemukan kesalahan serta kekeliruan terutama dalam menentukan ketepatan penetapan tingkat materialitas.

Hasil penelitian ini sejalan dengan penelitian yang dilakukan Khotiyah et al. (2016), Sarwini et al. (2014), Simanjuntak et al (2017), Halim dan Wulandari (2014), Aryani dan Anggraeni (2018), Nurasik \& Dewi (2018), Rahardjo dan Farouk (2019) yang menyatakan bahwa profesionalisme auditor berpengaruh positif terhadap pertimbangan tingkat materialitas.

\section{Pengaruh Pengalaman Auditor Terhadap Pertimbangan Tingkat Materialitas}

Hasil uji hipotesis kedua (H2) diterima, yaitu pengalaman auditor berpengaruh positif terhadap pertimbangan tingkat materialitas pada auditor yang bekerja di KAP wilayah DKI Jakarta. Pada tabel 6 coefficients dapat diketahui bahwa nilai sig. untuk uji t sebesar $0.005<0.05$, nilai $t$ hitung $2.879>1.987$ nilai t tabel. Nilai sig. dibawah 0.05 artinya bahwa variabel 
pengalaman auditor memiliki pengaruh yang signifikan terhadap pertimbangan tingkat materialitas. Dilihat dari nilai $\mathrm{t}$ hitung yang lebih besar dari nilai t tabel juga mengindikasikan bahwa variabel pengalaman auditor berpengaruh terhadap pertimbangan tingkat materialitas. Selanjutnya nilai Beta yaitu untuk melihat arah pengaruh dari variabel independen terhadap variabel dependennya. Pada nilai Beta di tabel 4 bisa dilihat bahwa hasilnya positif, maka pengaruhnya positif. Sehingga dapat disimpulkan H2 diterima, yaitu variabel pengalaman auditor (X3) berpengaruh signifikan positif terhadap pertimbangan tingkat materialitas (Y).

Pengalaman auditor akan menjadi bahan pertimbangan yang baik dalam mengambil keputusan dalam tugasnya. Pengalaman merupakan salah satu elemen penting dalam melaksanakan tugas audit di samping pengetahuan, sehingga cara memandang dan menanggapi informasi yang diperoleh selama melakukan pemeriksaan antara auditor berpengalaman dengan yang kurang berpengalaman akan berbeda, demikian halnya dalam mengambil keputusan. Semakin berpengalaman seorang auditor yang dilihat dari; (1) lama masa kerja, (2) banyaknya penugasan dan (3) banyaknya jenis perusahaan yang diaudit akan akan semakin bertambah pula pengetahuan, keahlian serta untuk menemukan kesalahan dan kekeliruan terutama dalam menentukan ketepatan penetapan tingkat materialitas.

Hasil penelitian ini mendukung penelitian Simanjuntak et al. (2017), Khotiyah et al. (2016), Sarwini et al. (2014), Sofia dan Damayanti (2017), Halim dan Wulandari (2014), Sitio (2018) yang menyatakan bahwa pengalaman auditor berpengaruh positif terhadap pertimbangan tingkat materialitas.

\section{Pengaruh Etika Profesi Terhadap Pertimbangan Tingkat Materialitas}

Hasil uji hipotesis ketiga (H3) diterima, yaitu etika profesi berpengaruh positip terhadap pertimbangan tingkat materialitas pada auditor yang bekerja di KAP wilayah DKI Jakarta. Pada tabel 6 coefficients dapat diketahui bahwa nilai sig. untuk uji $\mathrm{t}$ sebesar $0.000<0.05$, nilai t hitung $5.774>$ 1.987 nilai t tabel. Nilai sig. dibawah 0.05 artinya bahwa variabel etika profesi memiliki pengaruh yang signifikan terhadap pertimbangan tingkat materialitas. Dilihat dari nilai $t$ hitung yang lebih besar dari nilai $\mathrm{t}$ tabel juga mengindikasikan bahwa variabel etika profesi berpengaruh terhadap pertimbangan tingkat materialitas. Selanjutnya nilai Beta yaitu untuk melihat arah pengaruh dari variabel independen terhadap variabel dependennya. Pada nilai Beta di tabel 4 bisa dilihat bahwa hasilnya positif, maka pengaruhnya positif. Sehingga dapat disimpulkan H3 diterima, yaitu variabel etika profesi (X2) berpengaruh signifikan positif terhadap pertimbangan tingkat materialitas (Y).

Etika profesi auditor sangat penting dimiliki karena etika profesi akan menjadi dasar dalam membuat suatu keputusan oleh auditor dalam tingkat materialitas. Apabila etika profesi seorang auditor semakin tinggi maka semakin baik kemampuan auditor dalam menentukan pertimbangan tingkat materialitas akan semakin baik. Kepatuhan auditor pada kode etik profesi dalam menjalankan pekerjaannya berdasarkan prinsip-prinsip antara lain; 1) Prinsip Integritas, 2) Prinsip Objektivitas, 3) Prinsip Kompetensi Profesional dan Sikap Cermat Kehati-hatian, 4) Prinsip Kerahasiaan, 5) Prinsip Perilaku Profesional. Prinsip-prinsip tersebut merupakan hal-hal yang seharusnya dimiliki oleh seorang akuntan publik.

Hasil penelitian ini sejalan dengan penelitian Rahardjo dan Farouk (2019), Sitio (2018), Sofia dan Damayanti (2017), Aryani dan Anggraeni (2018), Khotiyah et al. (2016), Sarwini et al. (2014), yang menyatakan bahwa etika profesi auditor berpengaruh secara positif terhadap pertimbangan tingkat materialitas. 


\section{Simpulan Dan Saran}

Berdasarkan hasil analisis data dan pembahasan dapat ditarik kesimpulan bahwa, profesionalisme auditor memiliki pengaruh yang signifikan positif terhadap pertimbangan tingkat materialitas dalam proses audit laporan keuangan. Ini menunjukkan bahwa semakin tinggi profesional auditor, maka semakin tinggi pula pertimbangan tingkat materialitas yang dihasilkan auditor dalam proses audit laporan keuangan. Artinya, auditor yang memiliki pertimbangan audit profesional akan lebih tepat dalam mengaudit laporan keuangan sesuai dengan keadaan yang sebenarnya. Pengalaman auditor memiliki pengaruh yang signifikan posistif terhadap pertimbangan tingkat materialitas. Semakin banyak pengalaman seorang auditor yang dilihat dari lama masa kerja, banyaknya penugasan dan banyaknya jenis perusahaan yang diaudit akan semakin bertambah pula pengetahuan, keahlian serta untuk menemukan kesalahan dan kekeliruan terutama dalam menentukan ketepatan pertimbangan tingkat materialitas. Etika profesi memiliki pengaruh yang signifikan posistif terhadap pertimbangan tingkat materialitas. Semakin tinggi kepatuhan pada etika profesi seorang auditor dalam menjalankan pekerjaannya berdasarkan prinsip integritas, objektivitas, kompetensi profesional dan sikap cermat kehati-hatian, menjaga kerahasiaan, dan perilaku profesional, maka semakin baik kemampuan auditor dalam menentukan pertimbangan tingkat materialitas.

\section{Rekomendasi}

Adapun saran yang dapat diberikan di dalam penelitian ini adalah sebagai berikut: bagi auditor, diharapkan dapat menjadi tambahan referensi dan bahan evaluasi agar auditor menjadi lebih baik dalam menentukan pertimbangan tingkat materialitasnya, yaitu dengan lebih meningkatkan dan menjaga profesionalisme auditor, memperbanyak pengalaman mengaudit dan pentingnya memiliki etika profesi sebagai dasar dalam membuat suatu keputusan. Bagi peneliti selanjutnya diharapkan dapat memperluas area penelitian, tidak hanya di Jakarta Selatan dan Jakarta Pusat, sehingga bisa lebih digeneralisasikan. Diharapkan juga peneliti dapat menambah beberapa variabel independen lain yang diduga juga dapat mempengaruhi pertimbangan tingkat materialitas.

\section{Keterbatasan}

Adapun keterbatasan dari penelitian ini, yaitu dalam menyebarkan dan mengumpulkan kuesioner ke auditor yang bekerja di KAP yang terdapat di wilayah Jakarta. Penelitian ini memiliki nilai Adjusted $\mathrm{R}^{2}$ sebesar 58,7\%, hal ini menunjukkan masih banyak faktor-faktor atau variabel lain yang dapat mempengaruhi pertimbangan tingkat materialitas yg berada diluar penelitian ini, seperti due professional care, pengetahuan mendeteksi kekeliruan dan kualitas audit.

\section{Daftar Pustaka}

Ajzen, Icek. 1991. "The theory of planned behavior: organizational behavior and human decision processes." Organizational Behavior and Human Decision Processes Vol. 50 Issue: 2, pp. 179-211. https://doi.org/10.1016/07495978(91)90020-T.

Arens, A. A., Elder, R. J., \& Beasley. M. S. (2017). "Auditing and Assurance Services": Sixteenth Edition. London : Pearson.

Aryani, D. S. \& Anggraeni, S. D. (2018). "Pengaruh Profesionalisme Auditor Dan Etika Profesi Terhadap Pertimbangan Tingkat Materialitas Pada Kantor Akuntan Publik Di Wilayah Palembang". Jurnal Kompetitif. Palembang: Universitas Tridinanti Palembang. 
Ghozali. (2018). “Aplikasi Informasi Multivariate dengan Program IBM SPSS 25". Semarang: Universitas Diponegoro.

Hall, R. Vance; Lund, Diane, and Jackson, Deloris.,(1968). "Effects of teacher attention on study behavior". Journal of Applied Behavior Analysis, Vol. 1, Issue:1. pp. 1-12.

Halim, A. \& Wulandari, R. (2014). "Pengaruh Profesionalisme, Etika Profesi Dan Pengalaman Auditor Terhadap Pertimbangan Tingkat Materialitas Pada KAP Kota Malang”. Journal Riset Mahasiswa Akuntansi (JRMA) ISSN: 2337-5673. Vol. 2.

Haryono, J. (2001). "Dasar-Dasar Akuntansi Jilid 2". Yogyakarta : Bagian Penerbitan Sekolah Tinggi Ilmu YKPN.

Hastuti, D. T., Indarto, L. S., dan Susilawati, C. (2003). "Hubungan antara Profesionalisme Auditor dengan Pertimbangan Tingkat Materialitas dalam proses Pengauditan Laporan keuangan". Simposium Nasional Akuntansi VI, 1206-1220.

IAPI (2013). "Standar Profesional Akuntan Publik” (SPAP). Jakarta: Salemba Empat.

IAPI. (2018). "Kode Etik Profesi Akuntan Publik". Edisi Juli 2019. Penerbit IAPI., Jakarta.

Khotiyah, J., Jonathan, L. C. A. R. \& Lau, E. A. (2016). Pengaruh Profesionalisme Auditor, Etika Profesi Dan Pengalaman Auditor Terhadap Pertimbangan Tingkat Materialitas“. Jurnal. Samarinda: Fakultas Ekonomi Universitas 17 Agustus 1945. Diperoleh dari

https://pdfs.semanticscholar.org/fa98/87 f39f506a7acbad71613585b969cc8f80ea .pdf

Lestari, N.M.A., \& Utama, I.M.K. (2013) Pengaruh Profesionalisme, Pengetahuan Mendeteksi Kekeliruan, Pengalaman, Etika Profesipada Pertimbangan Tingkat Materialitas. E-Jurnal
Akuntansi Universitas Udayana. 5 (1): 78-92

Messier, William F., Steven M. Glover, Douglas F. Prawitt. (2014). "Jasa Audit dan Assurance”. Edisi 8. Jakarta: Selemba Empat.

Nugrahanti, T. P. (2012). "Pengaruh kompetensi, independensi dan etika auditor terhadap kualitas audit pada kantor akuntan public". http://repository.perbanas.id/xmlui/han dle/123456789/1671

Nugrahanti, T.P, \& Jahja, S. (2018). "Audit judgment performance: The effect of performance incentives, obedience pressures, and ethical perceptions". Journal of Environmental Accounting and Management. Vol. 6, No 3.,pp. 225-234. USA

Nugrahanti, T.P, \& Nurfaidzah (2020). "Dysfunctional Audit Behavior and Sign Off Premature Audit Procedures: Case Study of Jakarta Public Accounting Firm". Research Journal of Finance and Accounting. Vol 11, No 6;pp.21-31.

https://www.iiste.org/Journals/index.ph p/RJFA/article/view/52142

Nurasik \& Dewi, S. R. (2018). "Profesionalisme Dan Etika Profesi Sebagai Dasar Pertimbangan Tingkat Materialitas Akuntan Publik". Jurnal. Sidoarjo: Universitas Muhammadiyah Sidoarjo.

.Rahardjo, B. T. \& Farouk, U. (2019). "Effect of Professionalism of Auditors and Professional Ethics on Consideration of Materiality Levels (Empirical Study on Public Accounting Firm East Jakarta)". International Journal of Social Science and Public Policy (IJSSPP), Vol. 1(1).

Sarwini, N. K., Sinarwati, N. K. \& Yuniarta, G. A. (2014). "Pengaruh Profesionalisme Auditor, Etika Profesi Dan Pengalaman Auditor Terhadap Pertimbangan Tingkat Materialitas (Studi Empiris Pada Kantor Akuntan Publik di Bali)" Jurnal Bali: 
Universitas Pendidikan Ganesha. Vol., 2.

Sukrisno.,Agoes, (2016). “Auditing Petunjuk Praktis Pemeriksaan Akuntan Oleh Akuntan Publik" Edisi 4 Buku 1. Jakarta: Salemba Empat

Simanjuntak, I. N. W. R. P. \& Lumbantoruan, R. (2017). "Pengaruh Profesionalisme dan Pengalaman Auditor Untuk Mempertimbangkan Tingkat Materialitas Dalam Pemeriksaan Laporan Keuangan (Studi kasus pada kantor akuntan publik di wilayah Jakarta Pusat)". Jurnal Jakarta: Universitas Kristen Indonesia.

Sitio, R. (2018)."Pengaruh Profesionalisme Auditor, Etika Profesi dan Pengalaman Auditor Terhadap Pertimbangan Tingkat Materialitas". Jurnal Ilmiah Simantek, 2(3). ISSN. 2550-0414.

Sofia, I. P. \& Damayanti, R. T. (2017). "Pengaruh Pengalaman, Profesionalisme, Etika Profesi Auditor Terhadap Penentuan Tingkat Materialitas". Widyakala Vol. 4 No.2. ISSN 2337-7313.

Sugiyono. (2017). "Metode Penelitian Kuantitatif, Kualitatif, dan R\&D”. Bandung: Alfabeta

Tuanakotta, 2015. "Audit Kontemporer". Jakarta : Salemba Empat

Tubbs, R. M. (1992). "The Effect of Experience on the Auditor's Organization and Amount of Knowledge". The Accounting Review, 67, 4, 783-801.

\section{Tambahan}

Kuesioner Penelitihan https://docs.google.com/forms/d/e/1FAIpQ LSfOl1ZGwt3pXylUJjFDZ_a_5k13NCc56pBWucsyuv70n2AxA/ viewform 